\title{
The Calcium Silicate Powder Application On Broiler Litter To Improve Poultry Health
}

\author{
Arman Deskiharto \\ Center for Tropical Animal Studies - \\ $I P B$ University \\ Bogor, Indonesia \\ rayschwarz@ymail.com \\ Eko Sugeng Pribadi \\ Department of Infectious Diseases and \\ Veterinary Public Health \\ Faculty of Veterinary Medicine - IPB \\ University \\ Bogor, Indonesia
}

\author{
Asep Rakhmat \\ Center fo Tropical Animal Studies - \\ IPB University \\ Bogor, Indonesia \\ asepr40@gmail.com
}

\author{
Deddy Cahyadi Sutarman \\ Center fo Tropical Animal Studies - \\ IPB University \\ Bogor, Indonesia
}

\begin{abstract}
Broiler health could be impacted because litter is medium for microorganism growth, including gastrointestinal pathogens. This paper described the Calcium Silicate $(\mathrm{CaSi})$ powder application on broiler litter and their impact to the composting process. The Data showed that $\mathrm{CaSi}$ powder absorbed water from broiler litter and maintained litter pH around 7. Furthermore, composts made from manure that were used $\mathrm{CaSi}$ powder have more dry and low $\mathrm{C} / \mathrm{N}$ ratio than manure that were not applied with $\mathrm{CaSi}$ powder. According to these data, the application of $\mathrm{CaSi}$ in broiler litter was useful for reducing moisture in broiler litter so that it disturbed microorganism to grow in litter and haven a positive impact on waste cage management.
\end{abstract}

Keywords-Calcium Silicate, broiler, litter, compost

\section{INTRODUCTION}

Poultry industry is the largest livestock industry in Indonesia. The average number of national poultry population increased by $2.97 \%$ per year for broiler (Dirjennakkeswan Kementan, 2017). Largest population of broiler can be found in West Java, East Java and Central Java. Meanwhile, the large increasing production ofnatice chicken can be found in Central Java, East Java and West java (Muliany, 2016).

Litter has impact on animal's health. Litter can be good habitat for microbes growth, included pathogens that can be infected livestock. Various chicken gastrointestinal pathogens can be survived on litter. Litter can absorb several compounds, or gasses even though outside of the chickenhouse or stall. Various votalite gasses, such as ammonia, acrolein, methylamine, acetic acid, acetaldehyde and formaldehyde, will be released to environment, and can be impact to animal health when they will be inhaled. (Skóra et al., 2016). Amonia that trapped in litter and if inhaled by chicken will be caused irritation of respiratory tract mucosa (David et al., 2015; Maliselo and Nkonde, 2015). Irritated mucosa will stimulate stress and cause respiratory tract infection.

Chicken manure can be composted become fertilizer that can improve soil fertility and provide so many organic matter components. Chicken manure contain higher plant nutrients than the other livestock animal (Nuraini et al.
2016). More complete nutrients and other growth factors in manure can be provided higher than chemical fertilizers (inorganic). Chicken manure utilization as fertilizer will be improved envinromental quality because they can improve aeration, water retention, increase activity of various microbes in the soil, increase in available phosphor $(\mathrm{P})$ content and decrease $\mathrm{P}$ soil retention. Manure utilization will be available to low-cost agriculture practicing in plant nutrients requirements (Nuraini et al., 2016).

Calcium Silicate $\left(5 \mathrm{CaO} .6 \mathrm{SiO}_{2} .5 \mathrm{H}_{2} \mathrm{O}\right)$ has many functions for material industry such as good sealing correlated to expansion, and the ability to set in the presence of fluids, bioactivity to release of ions acting as epigenetic signals and good biological properties (Gandolfi et al., 2014). Calcium Silicate (CaSi) predicted can absord moisture and control $\mathrm{pH}$ in litter. Beside that, $\mathrm{CaSi}$ can improve quality of compost.

\section{MATERIALS AND METHODS}

\section{A. Experiment preperation}

The broiler experiment was started from December 2018-February 2019. Experiment for broiler are conducting at Field Laboratory of Vocational School, IPB University. The materials used were two hundreds seventy broilers Cobb CP 707 strain Day-Old Chicken (DOC), commercial feed for broiler, $\mathrm{CaSi}$ hard powdery granule, drinking water, supporting material; sugar, chicken vitamins, vaccine.

\section{B. Experimental lay-out}

The DOC was divided into three treatment groups, each of which treated 90 DOC with three replicating groups, each containing 30 DOC. Treatment Group A was the Control Group with the ground floor and rice husk layer. Group B was the group whose floor was original floor, rice husk and $0.5 \mathrm{~cm}$ thickness of $\mathrm{CaSi}$ powder $(\mathrm{CaSi}$ will be poured on the floor evenly). Group $\mathrm{C}$ was the group whose floor was original floor and rice husk mixed to mixed with 5 $\mathrm{kg} \mathrm{CaSi}$ powder per $10 \mathrm{~kg}$ of rice husk (mixed evenly). Broiler cage litter were replaced and changed weekly. 


\section{Composting process}

At the end of the trial, all manure from each treatment was collected to produce compost. About 1 liter of EM4 reagent were added and mixed to each manure group. After that, pile of manure were stored in dry place and every week pile of manure were stired. During process, pile of manure were kept in 1.5 meter and temperature in $40^{\circ}$ $60^{\circ} \mathrm{C}$. Compost harvest was 14 days.

\section{Sample collection and laboratory analysis}

Every week litter sample were collected $200 \mathrm{~g}$ each treatment group. Litter sample were process to analysis of $\mathrm{pH}$ value and moisture at Livestock Nutrition Laboratory, Faculty of Animal Husbandry, IPB University. Fresh manure were collected $200 \mathrm{~g}$ before composting process and composting manure were colected $200 \mathrm{~g}$. Manure sample were process to analysis of $\mathrm{C} / \mathrm{N}$ ratio at Soil Laboratory, Faculty of Agriculture, IPB University.

\section{E. Statistical analysis}

Data collected from this study were analyzed using analysis of variance (ANOVA) and Duncan Multiple Range Test (DMRT).

\section{RESULTS}

\section{A. Litter $p H$ value and moisture}

Tabel I present litter $\mathrm{pH}$ value from 14-days until 28days. At 21-days and 28-days, ph value were significantly different $(\mathrm{P}<0.05)$. Group $\mathrm{B}$ were significantly different between the other two groups at 21-days and Group $\mathrm{C}$ were significantly different between the other two groups at 28days. Based on this, ph value of Group B and C were higher than Group A.

TABLE I. LitTer Ph VALUe Collected From BRioler CAGES

\begin{tabular}{|c|c|c|c|}
\hline \multirow{2}{*}{$\begin{array}{c}\text { Treatment } \\
\text { Group }\end{array}$} & \multicolumn{3}{|c|}{ pH Value } \\
\hline & 14-days & 21-days & 28-days \\
\hline A & $6.4 \pm 0.21$ & $6.5 \pm 0.26^{\mathrm{a}}$ & $6.7 \pm 0.06^{\mathrm{a}}$ \\
\hline B & $6.3 \pm 0,10$ & $7.3 \pm 0.10^{b}$ & $6.8 \pm 0.25^{\mathrm{a}}$ \\
\hline $\mathrm{C}$ & $6.2 \pm 0.12$ & $6.3 \pm 0.06^{\mathrm{a}}$ & $7.3 \pm 0.06^{b}$ \\
\hline
\end{tabular}

Tabel II present litter moisture value were significantly different $(\mathrm{P}<0.05)$. Group $\mathrm{B}$ had highest litter moisture and Group $\mathrm{C}$ had litter lowest moisture than the other two groups. At 21-days, Group B had highest litter moisture during trial $(23.09 \pm 0.47 \%)$. At 14-days, Group A had lowest litter moisture during trial $(13.44 \pm 0.14 \%)$

TABLE II. LITTER MOISTURE COLLECTED FROM BRIOLER CAGES

\begin{tabular}{|l|c|c|c|}
\hline \multirow{2}{*}{$\begin{array}{c}\text { Treatment } \\
\text { Group }\end{array}$} & \multicolumn{3}{|c|}{ Moisture (\%) } \\
\cline { 2 - 4 } & 14-days & 21-days & 28-days \\
\hline A & $13.44 \pm 0.14^{\mathrm{a}}$ & $13.49 \pm 0.03^{\mathrm{a}}$ & $16.68 \pm 0.09^{\mathrm{a}}$ \\
\hline $\mathrm{B}$ & $22.86 \pm 0.43^{\mathrm{b}}$ & $23.09 \pm 0.47^{\mathrm{b}}$ & $21.84 \pm 0.45^{\mathrm{b}}$ \\
\hline $\mathrm{C}$ & $14.55 \pm 0.16^{\mathrm{c}}$ & $15.99 \pm 1.39^{\mathrm{c}}$ & $19.35 \pm 1.50^{\mathrm{c}}$ \\
\hline
\end{tabular}

Remark: *In the same column with a different superscript means differ significantly $(\mathrm{P}<0.05)$

\section{B. Manure composting}

Tabel III present ratio $\mathrm{C} / \mathrm{N}$ from fresh manure and composting manure were significantly different $(\mathrm{P}<0.05)$. Based on this, there were ratio $\mathrm{C} / \mathrm{N}$ decreasing from fresh manure to composting manure during 14 days. Group B and $\mathrm{C}$ were significantly different and showed more ratio $\mathrm{C} / \mathrm{N}$ decreasing from fresh manure to composting manure than Group A. Group B were showed higest ratio C/N decreasing than the other group.

TABLE III. RATIO C/N From Fresh MANURE AND COMPOSTING MANURE

\begin{tabular}{|l|c|c|}
\hline \multirow{2}{*}{$\begin{array}{c}\text { Treatment } \\
\text { Group }\end{array}$} & \multicolumn{2}{|c|}{ Ratio C/N } \\
\cline { 2 - 3 } A & Fresh manure $^{\text {Composting manure }}$ \\
\hline B & $28.66 \pm 0.73^{\mathrm{a}}$ & $21.46 \pm 0.49^{\mathrm{a}}$ \\
\hline $\mathrm{C}$ & $38.69 \pm 2.81^{\mathrm{b}}$ & $23.42 \pm 1.13^{\mathrm{b}}$ \\
\hline
\end{tabular}

Remark: *In the same column with a different superscript means differ significantly $(\mathrm{P}<0.05)$

\section{DISCUSSION}

Based Tabel I CaSi in litter affected the litter $\mathrm{pH}$ value. Based on Tabel I known CaSi powder and rice husk made $\mathrm{pH}$ value litter around 6.3-7.3. Garcês et al (2013) litter material like sand ( $\mathrm{CaSi}$ powder) had $\mathrm{pH}$ value is 7.3 and risk husk had $\mathrm{pH}$ value is 6.5. Increasing of $\mathrm{pH}$ value to Group A because $\mathrm{CaSi}$ is alkaline (pH value 10-11) (Gandolfi et al., 2014).

Based Tabel II CaSi in litter affected litter moisture. $\mathrm{CaSi}$ absorbed the water from cage environment inside the litter because $\mathrm{CaSi}$ particels had porosity $60-70 \%$. Because of that, litter moisture of Group B and $\mathrm{C}$ were higher than Group A. Increasing litter moisture would affect to reducing moisture in cage environment.

Based Table III all composting manure weren't fit $\mathrm{C} / \mathrm{N}$ ratio of Indonesia Standard (10-20) (BSN, 2004). C/N ratio decereasing from fresh manure to composting manure in broiler is significantly difference. $\mathrm{C} / \mathrm{N}$ ratio decreasing in Treatment Group B dan C broiler is more than Treatment Group A because $\mathrm{C} / \mathrm{N}$ ratio around 35 would occured maximum decomposition for broiler litter (Keener et al., 2014).

\section{ACKNOWLEDGMENT}

This research was supported by Taiheiyo Cement Corporation, Daiba Garden City Building, 2-3-5, Daiba, Minato-ku, Tokyo. The author also would like to acknowledge Center for Tropical Animal Studies (CENTRAS), Vocational School, Livestock Nutrition Laboratory, Faculty of Animal Husbandry, and Soil Laboratory, Faculty of Agriculture, IPB University.

\section{REFERENCES}

[1] [BSN] Badan Standardisasi Nasional. SNI 19-7030-2004 tentang Spesifikasi kompos dari sampah organisk domestik, 2004.

[2] B. David, C. Mejdell, V. Michel, V. Lund, and R.O. Moe, 2015. Air Quality in Alternative Housing System May Have an Impact on Laying Hen Welfare. Part II-Ammonia, Animals, vol. 5(3), pp. 886-896, September 2015.

[3] [Dirjennakkeswan] Direktorat Jendral Peternakan dan Kesehatan Hewan, Statistik Peternakan dan Kesehatan hewan, Jakarta: 
Direktorat Jendral Peternakan dan Kesehatan Hewan Kementerian Republik Indonesia, 2017, pp. 82.

[4] M.G. Gandolfi,F. Siboni,T. Botero, M. Bossu, F. Riccitiello, C. Prati, Calcium silicate and calcium hydroxide materials for pulp capping: biointeractivity, porosity, solubility and bioactivity of current formulations. J. Appl. Biomater. Funct. Mater., vol. 13(1) pp. 43-60, March 2015.

[5] A. Garcês, S.M.S. Afonso, A. Chilundo, and C.T.S. Jairoce, Evaluation of different litter materials for broiler production in a hot and humid environment: 1. Litter characteristics and quality, J. Appl. Poult. Res, vol. 22, pp. 168-176.

[6] H. Keener, M. Wicks, F. Michel, and K. Ekinci, Composting broiler litter, World's Poult. Sci. J., vol. 70, pp. 709-719, December 2014.

[7] P.S. Maliselo and G.K. Nkonde, Ammonia Production In Poultry Houses And Its Effect On The Growth Of Gallus Gallus Domesticus
(Broiler Chickens): A Case Study Of A Small Scale Poultry House In Riverside, Kitwe, Zambia. Int. J. Sci. Tech. Res., vol. 4(04), pp. 141-145, April 2015.

[8] H.P. Muliany, Outlook Komoditas Pertanian Sub Sektor Peternakan Pusat Data dan Sistem Informasi Pertanian, Jakarta: Sekretariat Jenderal Kementerian Pertanian, 2016.

[9] A. Nuraini, D. Sobardini, E. Suminar, and H. Apriyanto, Quantity and yield quality of french bean seed (Phaseolus vulgaris L.) marked solid organic fertilizer and chitosan liquid organic fertilizer, J. Kultivasi, vol 15(2) pp. 81-85, August 2016.

[10] J. Skóra, K. Matusiak, P. Wojewódzki, A. Nowak, M. Sulyok, A Ligocka, M. Okrasa, J. Hermann, and B. Gutarowska, Evaluation of Microbiological and Chemical Contaminants in Poultry Farms, Int. J. Environ. Res. Public Health, vol. 13(2), pp. 192, February 2016. 